\title{
Reflexões sobre a imagem: um estudo de caso
}

\author{
Bruno Souza Leal 1 \\ Universidade Federal de Minas Gerais \\ bsleal@ufmg.br
}

\begin{abstract}
Resumo: O trabalho reflete sobre o papel da imagem no telejornal, contrapondo a "teoria implícita" dos manuais de telejornalismo, por um lado, e as contribuições dos estudos sobre televisão e da análise do discurso de linha francesa, por outro. As reflexões têm como foco uma matéria exibida no Jornal da Globo de o9 de agosto de 2005.
\end{abstract}

Palavras-Chave: Telejornalismo; televisão; narrativa

Resumé: Cet article aborde le rôle de l'image dans le téléjournal, faisant une comparaison entre, d'un coté, la "théorie implicite" des manuels de télé-journalisme, et d'autre, les contributions des études sur la télévision et des travaux d'analyse du discours d'origine française. Ces réflexions ont comme sujet une émission du Jornal da Globo, daté du 9 aôut 2005.

Mots-clés: télé-journalisme; télévision; récit

Abstract:This paper analyses an small segment of TV Globo's Jornal da Globo in order to understand the functions of an image in telejournalism. To do so, it contrasts telejournalism handbooks' implicit "theory" to some academic approaches to television, such the ones of French discourse analysis

Key-words: telejournalism; television; narrative

Resumen: Este artículo reflexiona sobre las imágenes en la televisión, contrastando, por un lado, lo que dicen los manuales de periodismo y, de otro, las perspectivas académicas de los estudios de televisión y el análisis del discurso francés. En un segundo momento, enfoca un pequeño segmento de una noticia del "Jornal da Globo"

Palabras-claves: periodismo; televisión; narrativa

${ }^{1}$ Professor do Programa de Pós-Graduação em Comunicação da Universidade Federal de Minas Gerais. 


\section{Introdução}

O papel das imagens no telejornalismo encontra uma formulação bastante comum nos manuais ${ }^{2}$ de telejornalismo: elas são "representações do real". A expressão - freqüentemente uma afirmativa - parece não comportar questionamentos, seja sobre a natureza ou processos dessa representação, seja sobre o "real", seja sobre as imagens. O tom conclusivo, aparentemente pacificador, alicerça-se sobre o que se poderia chamar de uma "teoria implícita", difundida nas redações, na qual se baseariam os manuais e que organizaria não só uma concepção de imagem, mas também sua inserção nas matérias e sua relação com a palavra. Assim, por exemplo, Luciana Bistane e Luciane Bacellar (2005), afirmam: "Imagem é uma representação do real. Ao transmiti-la, a televisão transforma o espectador em testemunha"(BISTANE E BACELLAR, 2005, p.84). Além disso, "[i]magens também dão credibilidade e força às notícias, sobretudo às denúncias” (BISTANE E BACELLAR, 2005, p.41).

Na sua caracterização do telejornalismo, as autoras reconhecem o processo da notícia como enquadramento da realidade, porém, o apreendem em seus aspectos "mecânicos", o que na tevê seria operacionalizado, entre outros, pelo cinegrafista ao recortar o real em imagens. À crença, portanto, de um real dado, estável, préestabelecido - um material a ser recortado - soma-se o papel transmissivo, aparentemente indiferente da televisão e do jornalismo, que levam o mundo ao espectador, transformado em testemunha dos acontecimentos. Por outro lado, ao distinguirem "notícias" e "imagens", as autoras acentuam não só a natureza verbal das primeiras, como também o papel secundário, acessório, das segundas.

Nesse sentido, observa-se que a "teoria implícita" sustenta a estreita iconicidade das imagens e, com isso, sua condição inequívoca de "dar a ver" o mundo. Resultado de uma operação técnica, as imagens seriam portadoras de uma objetividade intrínseca, capazes de propiciarem credibilidade ao texto verbal e de autenticarem o testemunho do espectador. Com isso, afirma-se a televisão e o

\footnotetext{
2 Por "manuais" denomina-se aqui aqueles produtos editoriais voltados para "profissionais, estudantes e professores de jornalismo" e que se propõem a introduzir o leitor às técnicas e processos do fazer telejornalístico. É importante observar que os autores desses "guias práticos" são em sua maioria jornalistas experientes.Entre os "manuais" consultados, estão os de Bacellar e Bistane (2005), Barbero (1998) e Paternostro (1987).
} 
jornalismo como transparentes, como transmissores, como canais ou veículos cuja mediação, portanto, aconteceria sem especificidades, constrangimentos, construções. Em outras palavras, é como se se dissesse da imagem como âncora do espelho telejornalístico.

Em confronto com tal "teoria", erguem-se não só a chamada "perspectiva construcionista" do jornalismo, tal como nomeia TRAQUINA (1993;2002), mas também, no caso específico do telejornalismo, aqueles estudos que se dedicam ou à especificidade da televisão como dispositivo e fenômeno social ou à análise de discursos televisivos, em seus contratos, gêneros e mecanismos. A contraposição de tais estudos à "teoria implícita" traz à tona contradições e problemas fundamentais ao entendimento do telejornalismo hoje.

O percurso empreendido neste ensaio opta por recuperar parte as contribuições desses estudos e, com isso, delinear rapidamente esse conjunto de questões. Além disso, essa aproximação orienta um pequeno estudo de caso, elaborado a partir de um pequeno trecho de uma matéria veiculada num dos telejornais mais importantes do país. O objetivo deste trabalho é, assim, mapear e formular interrogações acerca do telejornalismo e seus mecanismos ${ }^{3}$, tendo em vista especialmente a diversidade e a complexidade dos papéis das imagens no telejornal, para além de uma função estritamente informativa ou documental.

\section{2) O telejornal e a televisão}

Ao longo dos anos 60 e 70, diversos trabalhos seminais, de filiações teóricas diferentes, como os de Raymond Williams e de Umberto $\mathrm{Eco}^{4}$, apontaram para a televisão como um fenômeno cuja tessitura e funcionamento obedecia a regras próprias, desafiadoras de dicotomias e conceitos bastante difundidos. Assim, por exemplo, Eco vai observar a invalidade da oposição ficção/realidade, afirmando que na tevê (e todos os seus produtos) a questão da verdade é da ordem da enunciação e

\footnotetext{
3 Este ensaio resulta dos trabalhos iniciais do projeto de pesquisa "Narrativas do Real: o realismo na tevê", desenvolvido junto ao Grupo de Pesquisa em Imagem e Sociabilidade/UFMG.

4 Trata-se, aqui, respectivamente, de "Television: tecnology and cultural form", publicado em 1974 e cuja edição de referência é a de 2003, e de, entre outros, "Obra aberta", de 1968, e "Viagem na irrealidade cotidiana", de 1983, mas que reúne artigos publicados ao longo da década anterior; no caso da "Obra aberta", a edição utlizada é a de 2003. Faz-se referência aqui apenas aos textos diretamente utilizados na confecção deste artigo.
} 
não do enunciado. Da mesma forma, Williams caracteriza a tevê como "fluxo" ininterrupto de imagens, um ritmo a partir do qual seus produtos seriam elaborados e no qual estariam integrados. No Brasil, Muniz Sodré, no seu conhecido "O Monopólio da Fala”, de 77, já havia observado tanto a importância do contato, associado à "função fática" de Jakobson, como elemento "essencial" à "expressão televisiva” como afirmado que, nesta, “...a palavra, o verbo, impõem seu poder ao elemento visual" (SODRÉ, 1977, p. 74)

Nessa perspectiva, o telejornal pode tanto visto como um dos produtos paradigmáticos da tevê, uma vez que portador explícito e referencial das características do fluxo televisual, como também um dos seus gêneros mais difíceis, dada a complexidade das relações que o envolvem. Algumas das características gerais de todo e qualquer "texto" televisivo, como serialidade, repetição e fragmentação ${ }^{5}$, estariam presentes de modo inequívoco no telejornal, o que problematizaria irrevogavelmente formas tradicionais ou senso comum de percebe-lo.

Por serialidade, entende-se aqui a "apresentação descontínua e fragmentada do sintagma televisual" (MACHADO, 2000), que se observa tanto internamente a um programa quanto na sucessão de episódios que o constituem. Uma edição de um telejornal, por exemplo, é composta por blocos, intervalos, chamadas, pequenas e grandes matérias, que ao mesmo tempo em que repetem a estrutura da edição anterior, deslocam-na e antecipam a edição seguinte.

Nesse sentido, John Ellis (1994) afirma que os "modos ficcionais e nãoficcionais de exposição de significados parecem convergir na televisão, sob o impulso das formas características da tv aberta, dos segmentos e das séries, e a sempre presente sensação da 'vida' da imagem da tv”. Ele conclui: “... o primeiro uso do formato da série parece ter sido o do jornal, infinitamente atualizando eventos e nunca os sintetizando" (ELLIS, 1994,p.145, no original em inglês).

A serialidade, mais que uma opção formal da programação, pode ser vista como resposta frente aos "limites" técnicos da televisão e à forma como ela se insere no cotidiano. Objeto doméstico, o aparelho de tevê tem tela pequena (se comparada ao cinema, por exemplo) e produz programas a serem consumidos na ritual rotineiro

5 A seriação ou serialidade e demais características são reconhecidas como marcas do "texto" televisivo por autores como Ellis (1994,) Duarte(2004), Jost(2004) Machado (2000), Balogh (2002), entre outros, em que pensem as diferenças entre eles. 
e disperso do espaço privado. Com isso, suas imagens, com pouca ou nenhuma profundidade de campo, são menos "densas" de informação e com alto grau de redundância. Além disso, a multiplicidade de canais, cada vez maior, e o controle remoto impõem um ritmo próprio ao fluxo televisual:

O surgimento do controle remoto delegou ao telespectador a tarefa de seleção e ordenação de fragmentos de programas que ele próprio optava para ver. A montagem desse verdadeiro quebra-cabeça(...) fez com que a própria televisão passasse a oferecer programas tão fragmentados que produzissem eles próprios o efeito de sentido do zapping. Com essa excessiva fragmentação, há uma exclusão de temas centrais: os produtos televisivos se constroem como fluxos resistentes ao significado, combinando a fragmentação temática com a incessante rotação dos mesmos elementos, de forma, pelo menos aparentemente, aleatória... (DUARTE, 2004, p.74)

Pode-se verificar que a imagem do espectador de televisão, em contraponto àquele do cinema, por exemplo, é marcada pela atenção difusa e precária, pelo interesse disperso e pelo talvez surpreendente papel de organizador final do sentido das imagens que correm no fluxo televisual. Umberto Eco (1968/2003), aliás, já havia proposto o termo "experiência" para caracterizar relação do receptor com o "ao vivo". Nesse caso, o autor italiano não só reconheceu pioneiramente as qualidades estéticas da tv, como nela observou uma espécie de dupla "poiesis": a narrativa televisual seria resultado de uma experiência de mediação e ao mesmo tempo produziria uma experiência na sua relação com o espectador.

Dessas reflexões resulta uma imagem de espectador um tanto mais complexa que aquela personagem que busca na imagem a credibilidade da notícia. A experiência da tevê é constituída não apenas o processamento da informação e a produção de significado, mas uma série de outras relações que envolvem a "materialidade" da linguagem, do signo, as suas dimensões fática e estética e os seus "efeitos de presença". Afinal, a "experiência" da televisão compreende, além daqueles elementos implicados diretamente na produção de significados, os ritmos e a composição das imagens, cores, formas, enquadramentos, sons e outros recursos que mobilizam sensível e emocionalmente o espectador e seu corpo.

A pergunta fica mais premente quando se percebe o telejornal, tal como faz MACHADO (2000), como “... uma colagem de depoimentos e fontes numa seqüência sintagmáticas, mas essa colagem jamais chega a constituir um discurso suficientemente unitário, lógico ou organizado a ponto de ser considerado 'legível' 
como alguma coisa 'verdadeira' ou 'falsa"' (MACHADO, 2000, p.110). Ou ainda, como faz DUARTE (2004), ao afirmar que “...ao promoverem os acontecimentos enquanto os dizem e ao transformarem atores sociais em discursivos, os telejornais fazem emergir uma verdade que é discursiva, não coincidindo, obrigatoriamente, com a verdade dos fatos: trata-se de operações com efeitos de sentido" (DUARTE, 2004, p.110/111).

Se a questão da verdade, no telejornal, é da ordem da enunciação e um efeito de sentido, o papel das imagens que o compõem foge àquele previsto, de documento mecânico do real. François Jost (2004), nas suas lições sobre televisão, nesse sentido, considera que "o telejornal, embora pretenda falar da realidade, observa-se que freqüentemente ele a reduziu ao visível, ao ponto de, às vezes, a existência dos acontecimentos depender da sua capacidade de ser visualizado" (JOST, 2004, p.84).

A natureza dessa visualização promovida pela tevê, porém, põe em questão a direta e estreita iconicidade das imagens. "Já é tempo de se admitir que, se a imagem é um signo, não se pode considera-la sob um único ângulo de relação com o mundo", afirma Jost (2004, p.88), que identifica pelo menos 3 possibilidades da imagem como signo ("signo do mundo", "signo do autor" e "signo do documento"), cada uma delas implicando uma "ancoragem" distinta. Sem entrar no mérito na tricotomia do autor, é importante frisar que seu pensamento desloca a imagem de uma relação préestabelecida, fixa e estática com o mundo, com os textos e o receptor.

Assim como ele, outros pesquisadores, às voltas com o discurso mediático, chegam a conclusões próximas. Patrick Charaudeau (1997), por exemplo, ao investigar o discurso da informação mediática, indica três efeitos e três funções para a imagem nos jornais televisuais. Os primeiros seriam efeitos de realidade, de ficção ou de verdade; as funções, de designação, figuração e visualização. Há certamente uma equivalência entre efeitos e funções e Charaudeau acentua respectivamente seu caráter de "ilusão", de "verossimilhança" e de "codificação". Ele alerta que a imagem na tevê é "a-contemplativa" e deve ser considerada nas características do dispositivo televisual e nas condições de enunciação.

Reconhecendo ainda uma complexa relação da palavra com a imagem no telejornalismo, Charaudeau concorda com aqueles que vêem o telejornal como às voltas com a verdade da enunciação e não com "a realidade". De fato, a cada 
função/efeito corresponderia uma estratégia enunciativa diferente e, com isso, a modos distintos de autenticação do relato. Para Charaudeau, sendo "pleno de ilusão de realismo e pleno de simulacros de verdade" é exatamente esse "fazer crer' que define o jornal televisivo" (CHARAUDEAU, 1997, p.213, no original em francês).

Anos antes de Charaudeau e Jost, Beat Münch (1992) já havia observado não só as diferentes funções das imagens na televisão, como feito distinção entre os papéis da imagem em movimento e das imagens fixas (incluindo ai os grafismos, as fotografias, etc). Para Münch, as imagens têm, para além do estritamente informativo, função de estimular (sensorial e emocionalmente) o espectador. Ao analisar matérias veiculadas em telejornais franceses, Munch observa que sua coerência textual ${ }^{6}$ tem um componente novo e indispensável, introduzido pelas imagens, que é o envolvimento emocional do espectador. Isso porque, para ele, a articulação entre palavra e imagem no jornalismo televisual não é estável nem direta. “A análise de nosso exemplo", diz ele, "mostrou que a imagem pode deter uma certa autonomia, sobretudo nas partes narrativas e não deve ser vista somente sob o parâmetro da congruência com a palavra" (MUNCH, 1992, p.221, no original em francês).

Como conclusão, Munch distingue três modos de articulação palavra/imagem, a saber:

a)palavra e imagens são esquematizadas de modo paralelo e produzem um esquema no qual a visualização é completada pela sua ancoragem espaço-temporal e pela conceitualização pela palavra;

b) palavra e imagem estão distanciados e a esta desempenha papéis diferentes, pertinentes à sua própria esquematização e à sua obrigatória relação com aquela;

c) a imagem não apresenta nenhuma esquematização própria, apresentandose exclusivamente como a concretização do plano verbal (MUNCH, 1992, p. 221)

Em que pese a distância entre os telejornais franceses e os brasileiros, por exemplo, as conclusões de Münch apontam não só para a diversidade de papéis da

${ }^{6}$ Coerência textual definida como “....a capacidade dos textos de construir, inseridos numa atividade discursiva, noções cognitivas e de as exprimir à superfície textual numa seqüência de enunciados coordenados" (MUNCH< 1992, p.195, no original em francês) 
imagem nos telejornais como também o esforço de adequá-los discursivamente. Ele observa inclusive que "mesmo apresentando uma esquematização própria, a imagem continua a ser apresentada como 'o fato"'(MUNCH, 1992, p.220). Com isso, ele acentua a distância entre os modos de operação, do fazer, do telejornal e sua apreensão - discursiva, mas não apenas - e apresentação por parte de seus produtores. Dessa forma, caracteriza-se ainda mais a distância entre a "teoria implícita" dos profissionais, dos quais os manuais se apresentam como seus "portavozes”, e o olhar crítico e reflexivo que se lança não só sobre essa fala, como também sobre os telejornais.

\section{3) A que servem os containeres?}

Nesse sentido, permanece como questão os papéis das imagens no telejornal, construídas e percebidas no cruzamento entre os valores, processos e ideais do jornalismo e os constrangimentos, peculiaridades e modos de ser da televisão. Um exemplo significativo da complexidade do problema pôde ser detectado no Jornal da Globo, em sua edição de 09 de agosto de 2006. Após a escalada e a primeira matéria, o telejornal apresenta um panorama econômico do dia, a partir da queda da cotação do dólar. A rigor, essa matéria não traz nenhum elemento excepcional: é previsível e rotineira e serve à reflexão exatamente pelo que tem de comum, de corriqueira, num telejornal noturno.

Resumo do dia, a matéria tem duração de 2 minutos e 50 segundos e é composta por dados sobre a moeda americana, bolsa de valores, exportações e inflação. Após a cabeça, lida por um dos âncoras, William Waack, a narração segue em off, pelo repórter Alan Severiano, cuja imagem surge na tela aos 1' 27" da matéria, que é encerrada pela outra âncora, Cristiane Pelajo. Ao longo da matéria, são apresentados gráficos com as cotações do dólar, da bolsa, do risco-país e a variação da inflação e duas entrevistas, com o secretário do Tesouro Nacional e um economista. As imagens são as mais diversas, envolvendo os entrevistados, enquadrados em close e plano médio, a bolsa de valores, pilhas de dólares, um escritório com funcionários e computadores. 
A matéria é claramente uma colagem de informações, imagens e reportagens anteriores e, num dos seus segmentos7, entre o 1'15" e o 1'26”, ou seja, por 11 segundos, a narração dedica-se a explicar a queda do dólar pelo aumento das exportações. As imagens, nesse trecho, são compostas por 3 planos, de respectivamente 2, 3 e 6 segundos (TAB.1. Esquematicamente, o trecho é como se segue:

Tabela 1 - O dólar e as exportações TEXTO VERBAL IMAGENS

Fora a crise política,

Plano geral fixo: guindastes, containeres e um caminhão que se desloca na parte de baixo do plano

tudo conspira para manter o dólar baixo.

As exportações que continuam batendo recordes e os juros altos, que atraem os investidores estrangeiros, mantêm o fluxo de dólares para o país
Plano geral fixo: containeres, guindastes

Plano geral e uma panorâmica descendente, dos guindastes até caminhões, passando por pilhas de containeres e um navio atracado.

De inicio, observa-se que a "notícia" está praticamente contida no texto verbal. A sua leitura, nas páginas deste artigo, permite a clara compreensão da informação com pouco ou nenhum prejuízo causado pela ausência das imagens. Pode-se supor inclusive que o texto verbal poderia muito bem ter sido lido numa passagem pelo repórter, sem maior comprometimento informativo da matéria. Mais que acentuar o caráter "radiofônico" do trecho, é importante ressaltar que tais imagens não produzem e apenas assessoram "o fato" noticiado.

Pode-se observar que o reconhecimento da informação ${ }^{8}$ contida no primeiro plano que compõe esse trecho é tributário de um repertório visual do espectador, que deve identificar na cena um porto e um material a ser exportado. As mudanças de plano não fazem saber, não dão visualidade a novos dados: todas as imagens

\footnotetext{
7 Optou-se neste ensaio pela análise de um pequeno trecho e não da matéria completa em razão das características argumentativas e de tamanho de um trabalho desta natureza Entende-se que essa opção não compromete os resultados e a reflexão proposta. 8 Utiliza-se o termo "informação" como forma de acentuar a dimensão estritamente "noticiosa" da reportagem, ainda que se tenha em vista as contradições que envolvem o termo "informação", tal como apontam, entre outros, Eco (2003) e Charaudeau (1997), que, por sua vez define "discurso informativo" como aquele cujo fim é um "fazer saber".
} 
retomam o mesmo repertório visual e poderiam ser trocadas de posição sem maiores implicações para o que está sendo dito pelo narrador. Redundantes, as imagens, porém, apresentam ritmo: há um crescendo em sua duração (2,3 e 6 segundos) que se completa no movimento panorâmico que constitui o terceiro plano. Com isso, verifica-se que a relação palavra e imagem apresenta uma dimensão sensorial, em que o ritmo dos planos acompanha o ritmo da narração. Além disso, apresentam também uma ancoragem temporal: nada indica que as imagens são "do dia", mas sua apresentação simultânea ao texto verbal as atualiza, produzindo sua "vivacidade".

Do ponto de vista da informação, palavra e imagem se encontram quando são mencionadas as exportações, termo que dá sentido ao que está sendo visto e que ocorre uma única vez, na metade do trecho - mas, é importante frisar, esse “encontro" é dependente do repertório visual do espectador, capaz de reconhecer um porto naquela paisagem de caixas de metal e guindastes.. Esse pequeno momento pode sugerir que a relação palavra/imagem no segmento em questão obedece ao primeiro modo de articulação identificado por Munch, em que, apesar de serem organizadas separadamente, é produzida uma ancoragem espaço-temporal entre elas, a partir especialmente do texto verbal. No entanto, talvez seja prudente observar não só a limitação da amostra, um fragmento de uma matéria relativamente longa, e especialmente a localização pontual dessa ancoragem.

Assim, mais que uma inserção fácil numa possível taxonomia, o fragmento oferece-se como pista das diversas possibilidades de articulação palavra/imagem no telejornalismo. A pouca importância informativa das imagens, nesse trecho, sugere ainda que se telejornal precisa produzir visualidade, e conseqüentemente fatos, é esse imperativo que primeiro estabelece a sua inserção nas matérias. Certamente não se pode generalizar um "modo de ser" das imagens no telejornal a partir desse exemplo, mas este serve pelo menos como indício, provocativo talvez, da inadequação de percebe-las exclusivamente sob um regime informacional.

O perfil da matéria parece ser decisivo aqui. Afinal, trata-se de um texto que apresenta um resumo dos acontecimentos do dia e não uma "notícia nova", um furo, ou mesmo traz uma informação captada diretamente na arena dos acontecimentos. Nesses casos, seria possível supor um outro regime para as imagens, o que indicaria, por um lado, a diversidade de papéis que elas podem desempenhar e, por outro, o 
quão tais funções seriam dependentes das circunstancias. Nos dois casos, contrariase, de qualquer forma, não só sua premência nas notícias telejornalísticas como sua óbvia informatividade.

Ao mesmo tempo, perguntar a que servem as imagens apresentadas faz surgir como resposta não só seu papel sensorial, fático, de sedução do olhar do espectador, quanto caracteriza este personagem como desatento e disperso. A redundância dos planos é consoante à dispersão, uma vez que permite que se retome visualmente a linearidade do relato oral após lapsos ou desvios de olhar. A experiência proporcionada pelo trecho, e possível de ser vislumbrada, é constituída por uma rede de relações entre palavra, sons e imagens que certamente envolvem a expressão de uma informação, mas que trazem outras dimensões que não são, pelo visto, nem acessórias nem desprezíveis nem excludentes. Ao contrário, são instâncias que se apresentam de modo articulado e interdependente.

A credibilidade, que deveria ser proporcionada pela "força das imagens", parece assim se apresentar menos como um resultado inequívoco delas do que de um esforço de enunciação para o qual contribuem, de modo mais decisivo, outros elementos, como as características do dispositivo, o gênero discursivo e o texto verbal. Ou seja, não são as imagens que se impõem por si só como fatos: elas são produzidas e organizadas de forma a se integrarem às necessidades, ao modo de dizer do telejornal. Com isso, é de se questionar de que afinal o espectador se tornaria testemunha9, que "realidade" as imagens estão tornando visíveis. Não é de hoje, aliás, que muitos indicam a televisão como produtora de uma realidade peculiar ${ }^{10}$. Nessa perspectiva, questões delicadas e fundamentais, como verdade, informatividade, e referencialidade, adquirem novos e instigantes contornos.

\footnotetext{
9 Silviano Santiago (1989) já havia, aliás, afirmado o olhar como lugar da experiência e do testemunho do "narrador pós-moderno" na ficção e no jornalismo

${ }^{10}$ É o caso de Eco (1984) Gumbrecht (1998a/1998b), Jost (2004), Machado (2000) e Duarte (2004), Charaudeau (1997), entre outros.
} 


\section{Referências:}

BALOGH, A. M. O discurso ficcional na TV. São Paulo: Edusp, 2002

BARBEIRO, H.; LIMA, P. R. Manual de telejornalismo: os segredos da notícia na TV. Rio de Janeiro: Campus, 2002.

BISTANE, L., BACELLAR, L. Jornalismo de tv. São Paulo: Contexto, 2005

CHARAUDEAU, P. Le discours d'information mediatique. Paris: Nathan, 1997

DUARTE, E. Televisão: ensaios metodológicos. Porto Alegre: Sulina, 2004

ECO, U. A estrutura ausente. São Paulo: Perspectiva; 1971

ECO, U. Viagem na irrealidade cotidiana. Rio de Janeiro: Nova Fronteira, 1984

ECO, U. Obra aberta. 9. ${ }^{\text {a }}$ ed. São Paulo: Perspectiva, 2003

ECO, U. Seis passeios pelo bosque da ficção. São Paulo: Cia. das Letras. 1994

ELLIS, J. Visible fictions. Edição revista. Londres: Rotledge, 1994

GUMBRECHT, H. U. Modernização dos sentidos. São Paulo: 34 letras, 1998a

GUMBRECHT, H.U Corpo e Forma. Rio de Janeiro: Ed. Uerj, 1998b

JOST, F. Seis lições sobre televisão. Porto Alegre: Sulina, 2004

LACALLE, C. El espectador televisivo. Barcelona: Editorial Gedisa,2001

MACHADO, A. A televisão levada a sério. São Paulo: Senac, 2000

MACHADO, A. Pré-cinemas, pós-cinemas. Campinas, 1997

MUNCH, B. Les constructions référentielles dans les actualiés télévisées. Berna: Peter Lang, 1992

PATERnostro, V. O texto na TV: manual de telejornalismo. São Paulo: Brasiliense, 1987

SANTIAGO, Silviano. O Narrador pós-moderno. In: Nas malhas das letras. São Paulo: Companhia das Letras, 1989.

SODRÉ, M. O monopólio da fala. Petrópolis: Vozes, 1977.

TRAQUINA, N. O que é jornalismo. Lisboa: Quimera, 2002

TRAQUINA, N. (org.). Revista de Comunicação e Linguagens: Jornalismo 2000. Lisboa: Relógio D’Água, 2002

TRAQUINA, N. (org.) . Jornalismo: questões, teorias e "estórias". Lisboa: Veja, 1993

VERÓN, E. El cuerpo de las imagenes. Bogotá: Grupo Editorial Norma, 2001

WILLIAMS, R. Television: tecnology and cultural form. (1.a ed: 1974). Londres: Routledge, 2003 
